\title{
Pomnik rodziny Strobandów w kościele pw. Wniebowzięcia NMP w Toruniu i jego treści
}

Pomnik Christiana i Johanna Strobandów w kościele Mariackim w Toruniu jest dobrze znany wszystkim zainteresowanym historią i dziedzictwem tego miasta (il. 1). Dzieło to było wielokrotnie wzmiankowane w literaturze, jednak nie poświęcono mu monograficznego opracowania, na które, biorąc pod uwagę jego historyczną i artystyczną rangę, bezsprzecznie zasługuje ${ }^{1 .}$ Jest to jedyne -

1 Pisali o nim m.in.: Jacob Heinrich ZeRnecke, Epitaphia in der St. Marien-Kirche zu Thorn, Continuirtes Gelehrtes Preußen oder vierteljähriger Auszug aus allerhsnd Preußischen Büchern nebst der Gelehrten Mäner Leben und MSC. Anmerckungen von Preußsichen Denckwürdigkeiten, Drittes Quartal M. DCC.XXV, s. 152-154; Julius Emil WeRnICKE, Die Kirchen der Stadt Thorn und ihres Gebietes, 1836, Akta Miasta Torunia, Archiwum Państwowe w Toruniu, Kat. II, X-25, fol. 273; Die Bau- und Kunstdenkmäler der Provinz Westpreußen, 6/7, bearb. v. Johannes HeIse, Danzig 1889, s. 290-291; Arthur SemRau, Die Grabdenkmäler der Marienkirche zu Thorn, „Mitteilungen des Coppernicus-Vereins für Wissenschaft und Kunst zu Thorn”, 7, 1892, s. 28-29, il. 4; Bolesław Makowski, Sztuka na Pomorzu. Jej dzieje i zabytki, Toruń 1932, s. 96-97; Gwido Chmarzyński, Sztuka w Toruniu. Zarys dziejów, [w:] Dzieje Torunia, red. Kazimierz TymiEnIEckI, Toruń 1933, s. 526; Witold KIEszKowski, Jan Zachwatowicz, Sprawozdanie z objazdu województwa pomorskiego, „Biuletyn Historii Sztuki i Kultury”, 2, 1933, nr 1, s. 11-12, 15, il. 15; Gwido CHMARZYŃSkI, Sztuka pomorska, [w:] Słownik Geograficzny państwa Polskiego i Ziem Historycznie z Polska Zwiqzanych, 1/2, Pomorze Polskie, Pomorze Zachodnie, Prusy Wschodnie, red. Stanisław ARnold, Warszawa 1936, s. 384; Lech KrzyżAnowski, Plastyka nagrobna Wilhelma van den Blocke, „Biuletyn Historii Sztuki”, 20, 1958, nr 3-4, s. 287; Jadwiga Puciata-PawŁowskA, $Z$ dziejów stosunków artystycznych Torunia i Gdańska w XVI i XVII wieku, „Teka Komisji Historii Sztuki”, 1, Toruń 1959, s. 218-220, il. 25; Lech KRzyżAnowski, Gdańska monumentalna rzeźba kamienna lat 1517-1628, Warszawa 1966, s. 67 (maszynopis przechowywany w Bibliotece Instytutu Historii Sztuki UAM w Poznaniu); TEnżE, Rzeźba kamienna na Pomorzu w 2. połowie XVI i na poczq̨tku XVII w., „Biuletyn Historii Sztuki”, 29, 1967, nr 4, s. 590; TENŻE, Blocke, Willem van den, hasło [w:] Słownik 
poza epitafium Caspara Frisiusa - zachowane do dziś monumentalne, wykonane $\mathrm{z}$ kamienia dzieło sztuki sepulkralnej upamiętniające członków toruńskich elit z czasu rozkwitu miasta w końcu XVI wieku². Jak głosi inskrypcja umieszczona w jego dolnej partii, powstało ono w 1590 roku. Do jego wykonania użyto typowego dla Prus szarego piaskowca, polichromowanego w celu imitacji czarnego wapienia i alabastru, bardziej szlachetnych materiałów stosowanych w ówczesnej rzeźbie niderlandzkiej³

artystów polskich i w Polsce działających. Malarze - rzeźbiarze - graficy, 1, Wrocław-Warszawa-Kraków 1971, s. 180; Danuta KRAKowIEckA-GóRECKA, Toruńskie inskrypcje kościelne do końca XVIII wieku, „Rocznik Toruński”, 19, 1990, s. 287-289; Jadwiga HABELA, Block (Blocke) Wilhelm, Willem van (von) den (der, dem), (ok. 1550-1628), hasło [w:] Słownik biograficzny Pomorza Nadwiślańskiego, 1, Gdańsk 1992, s. 122; Renata GoŁĄB, Nagrobek Jędrzeja Noskowskiego w Makowie Mazowieckim, „Ikonotheka”, 9, 1995, s. 106; Katarzyna MikockA-RAchuBowa, Block (Blocke), van den (van der; von dem), hasło [w:] Allgemeines Künstler-Lexikon. Die Bildenden Künstler aller Zeiter und Völker, 11, München-Lepizig 1995, s. 534; Jerzy DomasŁowski, Jarosław Jarzewicz, Kościót Najświętszej Marii Panny w Toruniu, Toruń 1998; s. 134-136, il. 38; Mariusz SMOLIŃskI, Willem $i$ Abraham van den Blocke a zagadnienie autorstwa nagrobków Konopackich, „Ikonotheka", 17, 2004, s. 101, il. 12; Piotr BiREcki, Wyposażenie wnętrza kościoła Mariackiego w Toruniu w okresie Reformacji, [w:] Dzieje i skarby kościoła Mariackiego w Toruniu. Materiały z konferencji przygotowanej przez Toruński Oddział Stowarzyszenia Historyków Sztuki przy współpracy Instytutu Zabytkoznawstwa i Konserwatorstwa Uniwersytetu Mikołaja Kopernika, red. Katarzyna KLuCzWAJD, Toruń 2005, s. 290; TENŻE, Sztuka luterańska na ziemi chełmińskiej od drugiej połowy XVI do pierwszej ćwierci XVIII wieku, Torun 2007, s. 329-330, il. 65; Michał WardzyńskI, The import and use of Belgian marble and limestone in small architecture and stone sculpture on Polish territory from the Middle Ages to the second half of eighteenth century, [w:] Actes du XV Colloque International de Glyptographie de Cardoue, ed. J.-L. van BELLE, Braine-le-Château 2007, s. 387; TENŻE, Marmury i wapienie południowo-niderlandzkie na ziemiach polskich od średniowiecza do 2. pot. XVIII w. Import $i$ zastosowanie w małej architekturze i rzeźbie kamiennej, „Biuletyn Historii Sztuki”, 70, 2008, nr 3-4, s. 322; Katarzyna Kluczwajd, Jacek Tylicki, Sztuka nowożytna, [w:] Anna BŁAżejewskA, Elżbieta PILEckA, Katarzyna Kluczwajd, Jacek Tylıcki, Bogusław Manseeld, Dzieje sztuki Torunia, Torun 2009, s. 199; Michał Wardzyński, Import kamieni i dziel rzeźby z Gotlandii i Olandii do Rzeczpospolitej (od XIII do 2. połowy XVIII w.), „Porta Aurea”, 9, 2010, s. 45-119.

2 O epitafium Frisiusa zob.: Franciszek SkIBIŃskI, Rzeźba kamienna w Toruniu ok. 1580-1650. Pomiędzy produkcją miejscową a importem z czołowych ośrodków rzeźbiarskich Rzeczypospolitej, [w:] Stare $i$ nowe dziedzictwo Torunia, (,Studia i materiały z dziedzictwa kulturowego Torunia i regionu" 1), red. Juliusz Raczkowski, Toruń 2013, s. 207-210. Przedstawione tam hipotezy, zwłaszcza w odniesieniu do materiału, zostały od tego czasu uzupełnione dzięki wiedzy zdobytej w wyniku prac konserwatorskich.

3 Zabieg taki był powszechnie stosowany, zob. np. wspomniane epitafium Frisiusa w Toruniu lub epitafium Eduarda Blemke w kościele Mariackim w Gdańsku. Odnośnie do materiałów kamieniarskich stosowanych w Prusach patrz przede wszystkim: WARDZYŃSKI 2007; WARDZYŃSKI 2008; WARDZyŃSKI 2010; Michał WARDzyŃSkI, Między Italia a Niderlandami. Środkowoeuropejskie ośrodki kamieniarsko-rzeźbiarskie wobec tradycji nowożytnej. Uwagi z dziedziny materiałoznawstwa, [w:] Materiał rzeźby. Między technikq a semantyka, red. Aleksandra LipińsKa, Wrocław 2009, s. 425-455. Zob. też m.in.: Hubert SyLwestrzaK, Jolanta Kachnic, Kamienne tworzywo sztuki, Toruń 2010, s. 250. 
Celem niniejszego artykułu jest próba odczytania treści pomnika Strobandów oraz jego kontekstu w społecznej przestrzeni ówczesnego miasta. Nie sposób jednak pominąć kwestii autorstwa, zwłaszcza, że jest on łączony z warsztatem czołowego rzeźbiarza gdańskiego końca XVI w., Willema van den Blockét. Architektoniczna struktura pomnika Strobandów wykazuje wiele cech wspólnych z grupą dzieł sztuki sepulkralnej powstałych w Prusach w przedziale wyznaczanym przez lata 1585 i 1594, zapewne w jednym warsztacie. Prócz pomnika Strobandów zalicza się do niej pomnik Johanna Brandesa i epitafium Eduarda Blemke w kościele Mariackim w Gdańsku oraz mocno uszkodzone epitafium Valentina von Bodeck w kościele św. Mikołaja w Elblągu ${ }^{5}$. Reprezentują one typ architektonicznego epitafium ściennego o niderlandzkiej genezie, o kompozycji opartej na antykizujących elementach architektonicznych, ornamentalnych i figuralnych, wypracowany w połowie XVI wieku i rozwijany przez takich artystów, jak Cornelis Floris i Hans Vredeman de Vries ${ }^{6}$. Tego rodzaju dzieła sztuki sepulkralnej, nazwane przez samego Florisa - lub też wydawcę, Hieronymusa Cocka - na stronie tytułowej cyklu Veelderleÿ nueve inuentien z $1557 \mathrm{r}$. wprost jako antÿcksche sepultueren, były całkowicie współczesnymi projektami opartymi na wybranych motywach architektonicznych i ornamentalnych zaczerpniętych $\mathrm{z}$ antyku, dostosowanych do aktualnych potrzeb wynikających z kulturowego kontekstu. W 2. połowie XVI wieku zyskały one dużą popularność w regionie bałtyckim, głównie w wyniku migracji niderlandzkich artystów, importu spektakularnych dzieł wykonanych w Niderlandach, jak np. książęce epitafia w Królewcu, oraz transferu wzorów graficznych.

Choć w grupie wymienionych wyżej dzieł widoczne są wyraźne wpływy wcześniejszych dzieł rzeźbiarskich oraz wzorników graficznych, odznaczają się

4 Atrybucję taką zaproponował Lech Krzyżanowski w swoim fundamentalnym artykule dotyczącym działalności Willema van den Blocke (KRzyżAnowski 1958). Atrybucja ta nie została podważona w późniejszej literaturze; przyjmuje ją również autor w rozprawie poświęconej temu rzeźbiarzowi, zob. Franciszek SkIBIŃski, Willem van den Blocke. Niderlandzki rzeźbiarz nad Bałtykiem w XVI i na poczatku XVII w., Torun 2015.

${ }_{5}$ Wszystkie przypisane Willemowi van den Blocke przez Lecha Krzyżanowskiego, zob. KRzYŻANOWSKI 1958.

6 O nich m.in. Antoinette Huysmans, Jan van Damme, Carl van de Velde, Christine van MulDERS, Cornelis Floris (1514-1575). Beeldhouwer, architect, ontwerper, Brussel 1996, s. 62-67; Peter FuHRING, Veelderleij niewe inuentien of antijcksche sepulturen ... libro secundo. Designs for epitaphs, tomb and surface decorations with scrollwork and grotesques, hasło kat. [w:] Hieronymus Cock. The Renaissance in Print, eds. Joris van GRIEKEN, Ger LuIJTEN, Jan van der STOck, New Haven-London 2013, s. 288-289; The New Hollstein Dutch \& Flemish Etchings, Engravings and Woodcuts 1450-1700, vol. XLVII, Hans Vredeman de Vries, 1, compiled by Peter FuHRING, ed. Ger LUiJTEN, Rotterdam 1997, nr 137-164, s. 129-150. O ich oddziaływaniu na terenach dawnej Rzeczpospolitej m.in. Renata SulEwska, Dłutem wycięte. Snycerstwo pótnocnych ziem Polski w czasach Zygmunta III Wazy, Warszawa 2004, s. 159-167. 
one dużą indywidualnością w ramach tej tradycji ${ }^{7}$ Ich struktura architektoniczna składa się z wertykalnych i horyzontalnych elementów właściwych dla klasycznych porządków architektonicznych tworzących wysuniętą przed lico edikulę złożoną z podpór $w$ formie kolumn lub kariatyd oraz belkowania (il. 2). $\mathrm{Z}$ wyjątkiem pomnika Brandesów, gdzie zastosowano bardziej wydatne profilowanie będące odwołaniem do sarkofagu, fartuch i część centralną dzieli profilowany, dwudzielny gzyms. Analogiczne jest też rozwiązanie trójczłonowego belkowania zamykającego część centralną, wyłamanego na osiach podpór, składającego się z architrawu o trzech kolejno rozszerzających się ku górze fasciae, bogato dekorowanego fryzu oraz wydatnego gzymsu (tym razem w rozumieniu elementu klasycznego porządku architektonicznego).

W każdym $\mathrm{z}$ wymienionych epitafiów występują motywy znane $\mathrm{z}$ innych dzieł wiązanych z warsztatem Willema van den Blocke. W przypadku toruńskiego pomnika kompozycja zwieńczenia przypomina analogiczny element nagrobka Ture Bielke w Linköping (zapewne przed 1600, il. 3), natomiast okuciowe uszaki dekorowane wicią roślinną odpowiadają analogicznym fragmentom cenotafu braci Andrzeja i Balthazara Batorych w Barczewie (przed 1599). Analogie dostrzegalne są też $w$ detalu architektonicznym. Dla przykładu, belkowanie wieńczące główną kondygnację pomnika przypomina belkowanie nieistniejących już nagrobków: książęcej pary w Królewcu (1578-1582) i Martina de Berzeviczy w Lisnowie (1593-1594).

Bliskie analogie do innych dzieł wiązanych z warsztatem mistrza Willema występują też w rzeźbie figuralnej. Pewne podobieństwo łączy figurę Temperantii w Toruniu i przedstawienie Patientii we wspomnianym wyżej pomniku królewieckim. Bliższe związki występują pomiędzy toruńskimi kariatydami oraz figurami w epitafium Christophera von Dohna w duńskim Odense (ok. 1586). Największe podobieństwo łączy jednak kariatydy flankujące główną kondygnację pomnika Johanna i Christiana Strobandów z figurą Iustitii w gdańskim epitafium Eduarda Blemke (il. 4-5). Obejmuje ono wolumen i proporcje ciała, kompozycję ukazanych w kontrapoście figur, a także ukształtowanie draperii i opracowanie detali fizjonomii. Warto zwrócić uwagę na relacje pomiędzy ciałem a draperią w obrębie nóg postaci, a także jej ukształtowanie, z drobnymi fałdami ciężko opadającej szaty, wijącej się wokół stóp. Nie ulega wątpliwości, że obydwie rzeźby są dziełem jednej osoby, podobnie jak Prudentia w epitafium Eduarda Blemke, a prawdopodobnie również rzeźba ukazująca Caritas w ratuszu w Chełmnie, gdzie zastosowano jednak inny,

\footnotetext{
7 O tym m.in. Franciszek SkIBIŃski, Manieryzm a rzeźba niderlandzka w Gdańsku, [w:] Maniera - manieryzm - manieryczność. Materiały LX Ogólnopolskiej Sesji Naukowej SHS, Gdańsk 24-25 listopada 2011, red. Jacek FrIEDRICH, Małgorzata OMILANowsKa, Jacek BIELAK, Warszawa 2012, s. 169-184.
} 
bardziej dynamiczny modus, wywodzący się z figury Immortalitas w pomniku Brandesów ${ }^{8}$ (il. 6).

Wobec złożoności praktyki warsztatowej i procesu wytwarzania monumentalnych dzieł rzeźbiarskich w epoce nowożytnej, opartego na współpracy członków warsztatu będących niejednokrotnie dobrze wyszkolonymi rzeźbiarzami, angażowanymi do wykonywania poszczególnych elementów monumentalnych struktur, trudno jednoznacznie wskazać autora omówionych wyżej rzeźb. Mogły one wyjść spod ręki samego mistrza, prawdopodobny jest jednak udziału któregoś spośród jego współpracowników. Musiałaby to być osoba zatrudniona w warsztacie kierowanym przez Willema van den Blocke od początku jego oficjalnej działalności w Gdańsku w roku 1584, przynajmniej do wczesnych lat dziewięćdziesiątych. Spośród znanych z przekazów źródłowych asystentów mistrza możliwym kandydatem - choć jest to na tym etapie badań niemożliwa do potwierdzenia hipoteza - wydaje się określany zazwyczaj w aktach cechu jako rzeźbiarz Philip van den Blocke, odnotowany $w$ pracowni Willema $w$ latach 1585-15939. Warto zauważyć, że po roku 1593, kiedy Philip odchodzi z warsztatu, rzeźby w tym typie zanikają, zaś w późniejszych pomnikach nagrobnych znacznie różniące się od siebie figury są już dziełem kolejnych asystentów, zatrudnianych przez mistrza do realizacji poszczególnych zamówień.

Wykonanie pomnika, będącego obiektem niniejszego artykułu, miał nakazać mocą swego testamentu zmarły w roku 1585 burmistrz toruński Johann Stroband $^{10}$. Życzenie ojca w kilka lat później spełnił jego syn Heinrich, sam będący już wtedy burmistrzem ${ }^{11}$. Wzniesiony w głównym kościele protestanckim

8 Rzeźba z Chełmna została przypisana Willemowi van den Blocke przez Eugeniusza Gąsiorowskiego, zob. Eugeniusz Gąsıorowski, Rynek i ratusz chelmiński, „Kwartalnik Architektury i Urbanistyki”, 10, 1965, s. 22. Atrybucję tę - wprawdzie raczej intuicyjną - niesłusznie odrzuciła Teresa Mroczko, zob. Teresa Mroczko, Caritas chelmińska, „Rocznik Historii Sztuki”, 17, 1988, s. 149-155.

9 Zob. Franciszek SkIBIŃSKI, Warsztat Willema van den Blocke w świetle akt gdańskiego cechu murarzy, kamieniarzy i rzeźbiarzy, „Biuletyn Historii Sztuki”, 72, 2010, nr 1-2, s. 87-89 oraz - w szerszym kontekście - TENŻE, Early modern netherlandish sculptors in Gdańsk and East-Central Europe. A study in dissemination through interrelation and workshop practice, [w:] Art and migration. Netherlandish artists on the move, 1400-1750, eds. Dulcia MeIJERs, Frits Scholten, Joanna WoodALL, „Nederlands Kunsthistorisch Jaarboek”, 63, 2013, s. 118-119.

10 Semrau 1892, s. 28. Na temat Johanna Strobanda zob. zwłaszcza Bogusław DyBaś, Krzysztof MikULSKI, Stroband, Jan (Johann, Hans), (1511-1585), burmistrz toruński, hasło [w:] Polski Słownik Biograficzny, 44/3, z. 182, Warszawa-Kraków 2006, s. 333-335.

11 Na temat postaci Heinricha Strobanda zob. m.in.: Marian Gumowski, Herbarz patrycjatu toruńskiego, „Roczniki Towarzystwa Naukowego w Toruniu”, 74, 1969, z. 3, Toruń 1970, s. 162-165; Henryk Rietz, Burmistrz Henryk Stroband (1548-1609). Twórca toruńskiego Gimnazjum Akademickiego, [w:] Księga pamiątkowa 400-lecia toruńskiego Gimnazjum Akademickiego, 1, red. Zbigniew ZDRójKowski, Toruń 1972, s. 13-39; Bogusław DyBAś, Burmistrz reformator. Wokót programu reformatorskiego Henryka Strobanda, „Zapiski Historyczne”, 66, 2001, z. 4, s. 29-43; TENŻE, Stroband (Strobandt, Strubant) Henryk (Henrich, Henrych) [I] (1548-1609), burmistrz tor., hasło [w:] Toruński stownik biograficzny, 3, Toruń 2002, s. 211-217; TENŻE, Stroband (Strobant, Strubant) 
Torunia, upamiętniał on zmarłych członków rodziny, a zarazem podkreślał jej rangę w społecznej przestrzeni miasta. Usytuowany w publicznym miejscu, powszechnie dostępny, monumentalny, kamienny pomnik, do tego prawdopodobnie wykonany przez najwyższej klasy rzeźbiarza pracującego dla królów i książąt, miał potwierdzać wiodącą rolę Strobandów w ówczesnym Toruniu ${ }^{12}$ (il. 7).

Dążenie do podkreślenia rangi rodu znalazło odzwierciedlenie w kompozycji oraz doborze elementów, będących nośnikami treści. Komemoracji jego członków służył wybór typu pomnika, a więc tzw. epitafium inskrypcyjnego, którego centralnym elementem jest inskrypcja upamiętniająca zmarłych ${ }^{13}$. Pozycję Strobandów podkreślono, odwołując się do długiej i zaszczytnej historii rodziny, wraz z pełnionymi przez jej członków urzędami, jak też do ich relacji z innymi pruskimi rodami patrycjuszowskimi. Upamiętniając dwa pokolenia rodu, budowano wizję jego ciągłości, podkreślając zarazem związki z miastem. Ciągłość rodziny była w kulturze tego czasu wartością fundamentalną, stąd zarówno w Rzeczpospolitej, jak i w całej Europie, często wznoszono pomniki i tworzono mauzolea upamiętniające dawno zmarłych członków szlacheckich i książęcych rodów ${ }^{14}$. Duże znaczenie nadano też postaciom małżonek zmar-

Henryk (Heinrich, Henrych) (I) (1548-1609), burmistrz toruński, hasło [w:] Polski Słownik Biograficzny, 44/3, z. 182, Warszawa-Kraków 2006, s. 328-331; Katarzyna Kolendo-KoRczAK, Propaganda reform burmistrza Henryka Strobanda w dekoracji Sali Rady z 1603 r. w ratuszu staromiejskim w Toruniu, "Zapiski Historyczne”, 74, 2009, z. 3, s. 37-60; Michał TARgowski, Strobandowie w Toruniu, [w:] Henryk Stroband (1548-1609) - burmistrz toruński. W czterechsetnq rocznicę śmierci, red. Krzysztof MikULSKI, Toruń 2010, s. 17-43.

12 O takiej funkcji dzieł sztuki sepulkralnej zwłaszcza Katarzyna CIEŚLAK, Die Danziger Epitaphien als eine gesellschaftsgeschichtliche Erscheinung, [w:] Sztuka Prus XIII-XVIII wieku, red. Michał WoźNIAK, („Studia Borussico-Baltica” 1), Toruń 1994, s. 179-198.

13 Jan Harasimowicz, Mors Janua Vitae. Śląskie epitafia i nagrobki wieku reformacji, Wrocław 1992, s. 147-156; Katarzyna CiEśLAK, Kościót - cmentarzem. Sztuka nagrobna w Gdańsku (XV-XVIII w.). „Dhugie trwanie” epitafium, Gdańsk 1992; TAż, Epitafia obrazowe w Gdańsku (XV-XVII w.), Gdańsk 1993; TAż, Tod und Gedanken. Danziger Epitaphien vom 15. bis zum 20. Jahrhundert, Lüneburg 1998; Marcin WisŁocki, Sztuka protestancka na Pomorzu 1535-1648, Szczecin 2005, s. 204-206; BiREcki 2007, s. 311-360. Warto przy tym podkreślić fakt, iż jest to jeden z najwcześniejszych przykładów tego typu realizacji na terenie Prus.

$14 \mathrm{~W}$ ostatnich latach ukazało się wiele ważnych studiów poświęconych różnym aspektom sztuki i - szerzej - kultury sepulkralnej w nowożytnej Europie, zob. m.in.: Nigel LLEWELLyN, Funeral monuments in Post-reformation England, Cambridge 2000; Andrea BARESEL-BrAND, Grabdenkmäler nordeuropäischer Fürstenhäuser im Zeitalter der Renaissance 1550-1650, Kiel 2007; Peter SHERLock, Monuments and memory in early modern England, Farnham 2008; Inga BrinkmanN, Grabdenkmäler, Grablegen und Begräbniswesen des lutherischen Adels. Adelige Funeralrepräsentation im Spannungsfeld von Kontinuität und Wandel im 16. und beginnenden 17. Jahrhundert, Berlin-München 2010; zob. też studia zawarte m.in. w tomach Demeures d'éternité: églises et chapelles funéraires aux $X V^{e}$ et $X V I^{e}$ siècles, (De architectura), études réunies par Jean GuILLAUME, Paris 2005 oraz Das Grabmal des Günstlings. Studien zur Memorialkultur frühneuzeitlicher Favoriten, („Humboldt-Schriften zur Kunst- und Bildgeschichte” 15), Hg. Arne Karsten, Berlin 2011. 
łych, Annie Stotten i Margarecie Esken, każdej z nich poświęcając osobne tablice inskrypcyjne. Małżeństwa z nimi walnie przyczyniły się do umocnienia pozycji Strobandów, obydwie należały bowiem do ścisłej elity pruskiego patrycjatu - Margareta była córką toruńskiego burmistrza, Frantza Eskena ${ }^{15}$.

Wobec szlacheckich korzeni rodu, potwierdzonych polskim indygenatem, istotne miejsce zajął program heraldyczny, bardzo rozbudowany w porównaniu z większością innych dzieł upamiętniających reprezentantów pruskich elit patrycjuszowskich ${ }^{16}$. W zwieńczeniu umieszczono dekoracyjny kartusz z herbem Strobandów, natomiast w dolnej partii, przy odpowiednich polach inskrypcyjnych - ujęte wieńcami kartusze $\mathrm{z}$ herbami rodzin, $\mathrm{z}$ których wywodziły się małżonki Christiana i Johanna Strobandów. Ponadto we fryzie znalazło się osiem tarcz z herbami przodków tych ostatnich ${ }^{17}$. W ten sposób podkreślono ciągłość i godność rodziny, jej szlacheckie pochodzenie oraz relacje z innymi rodami. Równie rozbudowany program heraldyczny pojawia się jedynie w nielicznych pomnikach i epitafiach patrycjatu wielkich miast pruskich. W Gdańsku były to pomniki upamiętniające osoby należące do rodów Schachmann, Kempen i Zirenberg, a więc najściślejszej tamtejszej elity ${ }^{18}$.

Uzupełnieniem inskrypcji i heraldyki, będących w tym przypadku głównymi nośnikami treści, są rzeźby współtworzące program ideowy dzieła. Ukazują one personifikacje czterech cnót kardynalnych, Iustitia, Prudentia, Temperantia i Fortitudo, oraz trzech cnót teologalnych, Fides, Spes i Caritas, przy czym tę ostatnią określono tu jako Amor, prawdopodobnie odnosząc się do koncepcji Amor Dei. Pomnik wieńczyła zaginiona dziś rzeźba, ukazująca personifikację Immortalitas.

Podejmując próbę interpretacji tego programu warto sięgnąć po nie w pełni dotąd wykorzystane w badaniach nad sztuką dawnego Torunia źródła pisane. Należy do nich mowa pogrzebowa dla Johanna Strobanda autorstwa Martina Trisnera, a ściślej mówiąc - wstęp do jej wersji opublikowanej w roku $1586^{19}$.

\footnotetext{
15 Na temat koligacji rodzinnych jako drogi awansu społecznego w nowożytnym Toruniu zob.: Alina Kardas, Elity władzy w Toruniu w XVII wieku. Mechanizmy kształtowania się $i$ wymiany grup społecznych, Toruń 2004, s. 190-194.

16 CiEŚlAK 1992, s. 54-59.

17 Na temat heraldyki we wnętrzu kościoła Mariackiego w Toruniu zob.: SEMRAu 1892; BIREckI 2007, s. 338-341, a ostatnio Krzysztof Mikulski, Tarcze herbowe z kościoła Mariackiego $w$ Toruniu, Warszawa 2015.

18 CIEŚLAK 1992, s. 55.

19 Martinus TrISNER, Leichpredigt, aus dem XXV. Capitel Genesis, von des Patriarchen Abrahams [...] Abschied, bey der Begrebniss des [...] Herrn Johann Stroband des Eltern, Burgermeisters der Koeniglichen Stadt Thorn [...] Anno 1585, Thorn 1586. Wspomina o nim m.in. BIRECKI 2007, s. 330, przyp. 63 (tam dalsza literatura). Jest to kolejne, obok fragmentów Ultima Verba i Historia Antichristi Konrada Grasera Starszego, źródło wskazujące na zainteresowanie protestanckich elit intelektualnych ówczesnego Torunia kwestiami dzieł sztuki znajdujących się w przestrzeni
} 
Wypowiedź członka toruńskich elit dotycząca funkcji popularnych tu dzieł sztuki sepulkralnej, bezpośrednio związana z omawianym pomnikiem, zasługuje na baczną uwagę, nawet jeśli powstała przynajmniej kilka lat przed jego wykonaniem.

We wstępie Trisner, pastor i profesor toruńskiego gimnazjum, zdefiniował funkcje dzieł sztuki sepulkralnej - określanych tu zbiorczo jako epitafia - oraz umieszczonych w nich inskrypcji ${ }^{20}$. Pierwszą z nich, szczególnie istotną w kontekście pomnika Strobandów, było podkreślenie i upamiętnienie cnót zmarłych, tak, by mogli oni cieszyć się wieczną sławą. Przy tej okazji Trisner przywołał popularną sentencję vivit post funera virtus, a także słowa Psalmu 112 (111), wers 6: „in memoria aeterna erit iustus”. Bliska zależność pomiędzy słowami Trisnera a programem pomnika Strobandów nie ulega wątpliwości, wyjaśniają one bowiem sens figuralnego programu dzieła, wskazując na związek pomiędzy wizerunkami siedmiu cnót a wieńczącą go personifikacją Nieśmiertelności. Ujęcie takie thumaczy też brak symboliki wanitatywnej, popularnej w sztuce sepulkralnej w Prusach.

Wyrażone przez Trisnera przekonanie o wiecznym trwaniu cnoty pojawia się w wielu drukach emblematycznych, dostarczających ważnego kontekstu interpretacyjnego dla toruńskiego pomnika. Jak wiemy choćby dzięki studiom Katarzyny Kolendo-Korczak, dotyczących zniszczonego w 1703 roku a powstałego również z inicjatywy Heinricha Strobanda stropu Sali Rady toruńskiego ratusza, druki tego rodzaju cieszyły się dużą popularnością wśród tutejszych elit ${ }^{21}$. Do najciekawszych $w$ omawianym kontekście należy emblemat Jeana-Jacquesa Boissarda, zamieszczony w pierwszym tomie jego Emblematum liber, gdzie za motto posłużyły przywołane przez Trisnera słowa „vivit post funera virtus"22 (il. 8). Emblemat o zbliżonej treści, rozpoczynający się od motta „Sola virtus est funeris expers", opublikowany został również w drugim tomie jego Emblematum liber ${ }^{23}$. Jego treść jest bardzo bliska wymowie pomnika Strobandów, wskazanej

kościołów, zob.: Franciszek SkIBIŃSkI, Konrad Graser Starszy i Johann Regius o kulcie obrazów. Przyczynek do dziejów sztuki w nowożytnym Toruniu, „Zapiski Historyczne”, 76, 2011, z. 2, s. 7-16.

20 Warto zaznaczyć, iż epitafiami nazywano ówcześnie w Prusach również monumentalne pomniki nagrobne, jak te upamiętniające księżną Elżbietę w Królewcu lub króla Szwecji Jana III, przeznaczony do Uppsali.

21 Kolendo-Korczak 2009; por. Katarzyna Kolendo-KorczaK, Praecepta politica $w$ toruńskim ratuszu. Niezachowany cykl malowidet z Sali Rady z 1603 roku i jego europejski kontekst, Warszawa 2014. Sam Heinrich Stroband zalecał wykorzystanie motywów zaczerpniętych z dzieła Claude'a Paradine’a (TAMżE, s. 330-331, 333-334, 346-347). Autorka wykazała ponadto, że komponując program stropu korzystano też zapewne $\mathrm{z}$ innych druków.

22 Jean Jacques Boissard's Emblematum Liber. Emblemes latins. Metz : A. Faber, 1588. A facsimile edition using Glasgow University Library SM Add 415, with a critical introduction and notes by Alison ADAMs, Turnhout 2005, nr 19, s. *32-"34.

23 Jani Jacobi Boissardi Emblematum Liber, Frankfurt 1593, („Emblematisches Cabinet” 12), ed. Ernst BenZ, Hildesheim-New York 1977, nr 47, s. 94-95. 
przez Trisnera: „nihil est in hoc orbe terrarium quod sit perpetuum; sola virtus thesaurus est homini constans, et peculium aeternum. [...] Virtus est immortalis".

Częste w nowożytnej sztuce sepulkralnej odwołanie do cnót miało zarówno chrześcijańską, jak i klasyczną genezę. W kontekście pomnika Strobandów warto przywołać - sięgającą filozofii Platona, Arystotelesa i stoików - koncepcję dotyczącą słusznej i zasłużonej nagrody za cnotę. Przedstawienia cnót w dziełach sztuki sepulkralnej służą oczywiście wychwalaniu zmarłego, ale zależność tę można odwrócić - to z obecności cnót w charakterze zmarłego wynika konieczność wywyższenia go, m.in. poprzez odpowiedni pomnik ${ }^{24}$. W myśl założeń Arystotelesa, który w Etyce nikomachejskiej argumentował, iż cnota uzasadnia dumę, pomniki eksponujące cnoty nie byłyby więc wyrazem pychy, lecz raczej uzasadnionej dumy ${ }^{25}$. Rangę cnoty podnosiła trudność jej zdobycia, co podkreślała zarówno myśl antyczna, jak i słowa Pisma Świętego ${ }^{26}$. W kontekście wieńczącej pomnik Strobandów personifikacji Immortalitas należy też podkreślić, iż cnotę uznawano za ostoję wobec kruchości, zmienności i marności świata.

Zbliżone koncepcje, choć w różnych ujęciach, pojawiają się też w innych dziełach sztuki sepulkralnej wzniesionych w tym czasie w Prusach. Jednym z nich jest wspomniany wyżej pomnik epitafijny Johanna Brandesa i jego żony Dorothei w Gdańsku (il. 9). Także tu centrum zajmuje tablica inskrypcyjna. Rolę pomnika akcentuje dodatkowo wprowadzenie rzeźbionych popiersi reprezentujących Brandesa i jego małżonkę ${ }^{27}$. Jednocześnie obecny jest tu program religijny, choć pozbawiony bezpośrednich odniesień biblijnych. Część centralną ujmują rzeźby (kariatydy/kanefory), będące personifikacjami cnót Fides i Spes, w zwieńczeniu znalazły się natomiast personifikacje Pracy (Labor), Śmierci (Mors) i - podobnie jak w epitafium Strobandów - Nieśmiertelności (Immortalitas). Ich sens tłumaczy inskrypcja znajdująca się we fryzie belkowania dzielącego fartuch od głównej kondygnacji pomnika: „In terris labor est. Requies in morte. Fide spes nititur, in coelis vita perennis erit”. Doczesne życie, nieubłaganie kończące się śmiercią, jest pełne trudu, jednak podążając za Wiarą i Nadzieją osiągnąć można nieśmiertelnośćc ${ }^{28}$.

24 Odnośnie do wywyższenia poprzez cnotę patrz: Estera LAsocińskA, „Cnota sama z mądrościa jest naszym żywotem”. Stoickie pojęcie cnoty w poezji polskiej XVII wieku, („Studia Staropolskie. Seria Nova", 6 [62]), Warszawa 2003, s. 49-55.

25 TAMżE, s. 49.

26 Wg Lasocińskiej wizja cnoty ukrytej w niedostępnym miejscu, na końcu trudnej i uciążliwej drogi, ma wiele źródeł, m.in. temat Herkules in bivo (źródłem są tu Memorabilia Ksenofonta), Tabula Cebetis (na ten temat zob. m.in.: Reinhart SchleIER, Tabula cebetis oder „Spiegel del Menschlichen Lebens / darin Tugent und untugent abgemalet ist". Studien zur Rezeption einer antiken Bildeschreibung im 16. und 17. Jahrhundert, Berlin 1973) oraz - a może przede wszystkim - Ewangelia św. Mateusza 7,14; zob. TAMżE, s. 58-62.

27 O funkcji portretu w pomnikach epitafijnych najpełniej: CIEśLAK 1992, s. 33-54.

28 Błędne thumaczenie i chybioną interpretację tej inskrypcji podaje Ewa Zapolska, zob.: Ewa Zapolska, Cnoty teologalne i kardynalne, Kraków 2000, s. 107. 
Sformułowania odpowiadające pierwszej części inskrypcji, w różnych wariantach, dość często występowały w pismach średniowiecznych i nowożytnych, również protestanckich. Stanowiły one odwołanie zarówno do źródeł chrześcijańskich (przede wszystkim Księgi Genesis, 3: 17-19 i Księgi Hioba, 5:7), jak też klasycznych tekstów antycznych ${ }^{29}$. Jako ilustrację można przywołać rycinę Hieronymusa Wierixa z 1579 roku, ukazującą człowieka zrodzonego do pracy ${ }^{30}$. Druga część ma już oczywiście genezę chrześcijańską, przy czym trudno tu mówić o wyraźnym zróżnicowaniu konfesyjnym - może poza pominięciem trzeciej z cnót kardynalnych, Caritas, akcentowanej przez katolików - odwołującej się do myśli zawartej w wielu tekstach teologicznych. Jako świadectwo wizualne można tym razem przywołać - poza licznymi przedstawieniami samych cnót - narracyjno-alegoryczną rycinę Willema van Haecht według Ambrosiusa Franckena z 1578 roku, ukazującą człowieka (homo), któremu Łaska (Gratia) i Światło Prawdy (Lumen Veritatis) nakazują podążać ku zstępującym z niebios postaciom cnót ${ }^{31}$.

W przypadku pomnika Brandesów program ikonograficzny, na który również składają się przedstawienia cnót i nieśmiertelności, zdaje się więc mieć nieco inny wydźwięk niż w przypadku pomnika Strobandów. Ostateczny cel cnoty - nieśmiertelność - postrzegana jest tu jako zbawienie duszy, nie zaś ziemska pamięć i chwała. Zbliżona, choć nieco inaczej wyrażona idea wiążąca cnotę, wiarę i nieśmiertelność, pojawia się natomiast w innym źródle powiązanym z pomnikiem Strobandów, mianowicie inskrypcji, która miała znajdować się na elewacji kamienicy należącej do tej rodziny ${ }^{32}$. Nieznany autor pisał tu: „si fide \& spe in Christum Servatorem tuum ad finem usqu perseveras, vitam hanc fragilem in sempiternam excelso transiens animo potes cum morte commutare, vereq eris beatus \& immortalis”33. Przedstawiono tu drogę prowadzącą

29 Na temat koncepcji labor zob. m.in.: Ilja M. Veldman, Images of labour and diligence in sixteenth-century Netherlandish prints. The work ethics rooted in civic morality or protestantism, „Simiolus”, 21, 1992, s. 227-264; TAż, Images of diligence and labour: the secularization of the work ethic, [w:] TEjżE, Images for the eye and soul: function and meaning in Netherlandish prints (1450-1650), Leiden 2006, s. 171-192; TAż, Representations of labour in late sixteenth-century Netherlandish prints: the secularization of the work ethic, [w:] The idea of work in Europe from antiquity to modern times, eds. Josef EHMER, Catharina LIs, Farnham 2009, s. 149-176.

30 Veldman 1992, fig. 2; Veldman 2009, fig. 6.1.

31 www.rijksmuseum.nl/en/search/objecten? $\mathrm{p}=4 \& \mathrm{ps}=12 \&$ maker $=$ Willem + van + Haecht $+(\mathrm{I}) \&$ ii=9\#/RP-P-1906-185,39 (dostęp: 15 VIII 2015).

32 Kolendo-KorczaK 2014, s. 260. Tekst inskrypcji - na co wskazuje autorka - opublikowany został w czasopiśmie: Das Gelahrte Preußen, II, 3 (1723) (IV), fol. 135-165, Nachricht von Henrico Strobando I, II \& III, fol. 148-149. Inskrypcja cytowana przez Kolendo-Korczak wg Das Gelahrte Preußen pochodzi w rzeczywistości z żywota Heinricha Strobanda zamieszczonego w: Melchior ADAM, Vitae Germanorum Jureconsultorum Et Politicorum, Qvi Superiori Seculo, Et Quod Excurrit, Floruerunt, Heidelbergae, excudit Johannes Georgius GREYDER, 1620, fol. 425.

33 Cyt. za: Kolendo-Korczak 2014, s. 260. 
do życia wiecznego, szczęścia i nieśmiertelności, wspominając ten sam sposób osiągnięcia celu, który podkreślono też w pomnikach Brandesów, a więc podążanie za cnotami Wiary i Nadziei.

Podobnie pisał Trisner we wstępie do wspomnianej mowy pogrzebowej. Według niego drugim - obok podkreślenia cnót prowadzących do nieśmiertelności - celem epitafium było wyznanie wiary w zmartwychwstanie i zbawienie na Sądzie Ostatecznym. Toruński pastor przywołał tu słowa Prudencjusza, wedle których człowiek nie umiera, a tylko zasypia w oczekiwaniu na życie wieczne. Wyczerpujące studia poświęcone protestanckiej sztuce sepulkralnej wskazują, iż bardzo często niosła ona taką właśnie treść ${ }^{34}$. Jej realizację ukazują wspomniane już epitafia Eduarda Blemke w Gdańsku oraz Valentina von Bodeck w Elblągu, wykonane niemal równocześnie z pomnikiem Strobandów. Zestawienie ich z tym ostatnim jasno ukazuje jego odmienność, dostarczając znakomitego materiału porównawczego, bowiem pomniki i epitafia powstałe zapewne w tym samym warsztacie - o czym była wyżej mowa - odznaczają się podobną strukturą, przez co można zakładać, iż odrębności między nimi wynikają przede wszystkim z różnicy programu, a więc ich zamierzonych treści.

W centrum epitafium Blemkego znalazła się scena Wizji Ezechiela, należąca do najczęściej spotykanych odniesień do biblijnej obietnicy zmartwychwstania $^{35}$. Towarzyszą jej dwa cytaty biblijne, będące - zgodnie z protestancką zasadą sola scriptura - ostatecznym potwierdzeniem tej wiary. Odwołanie do zmartwychwstania pojawia się też w zwieńczeniu, tym razem w formie emblematycznej. Ukazano tu zboże wyrastające z martwego ciała, nowe życie powstające ze śmierci. Scenie tej towarzyszy tekst, częściowo zaczerpnięty z Prudencjusza - co warte odnotowania w kontekście kazania Trisnera - „ut semina sicca virescunt, sic corpora nostra resurgent”. Autor programu epitafium mógł się tu odwołać do emblematów, jak te autorstwa Claude’a Paradina lub Jean-Jacquesa Boissarda ${ }^{36}$. Szczególnie wymowny jest emblemat Boissarda, gdzie obok przedstawienia zboża wyrastającego z kości ukazano zmartwychwstałych ludzi zwracających się ku Chrystusowi (il. 10). Scena Wizji Ezechiela wraz z towarzyszącym jej tekstem biblijnym oraz przedstawienie emblematyczne w zwieńczeniu tworzą ideową oś epitafium, podkreślają obietnicę zbawienia - w zgodzie z jednym z dwóch celów epitafium wskazanych przez Trisnera.

34 Jan Harasimowicz, Treści i funkcje ideowe sztuki śląskiej reformacji (1520-1650), Wrocław 1986; Harasimowicz 1992; CieślaK 1992; CieślaK 1993; CieślaK 1998; Wiseocki 2005; BIRECKI 2007.

35 Cieślak 1993, s. 30-35; Harasimowicz 1992, s. 118-124; WisŁocki 2005, s. 215-216.

36 Claude Paradine, Devises Herö̈ques, with introduction by Alison Sounders, Aldershot 1989, s. 258-259; Jean Jacques Boissard's Emblematum Liber. Emblemes latins. Metz: A. Faber, 1588. A facsimile edition using Glasgow University Library SM Add 415, with a critical introduction and notes by Alison AdAMs, Turnhout 2005, nr 15, s. "27-"29. 
Bardzo podobny program zastosowano też w epitafium Valentina von Bodeck. Jak wskazuje wzmianka zawarta w Variorum in Europa itinerum deliciae Nathana Chytraeusa, zbiorze inskrypcji wydanym w Heilbronn w 1594 ro$\mathrm{ku}, \mathrm{w}$ jego centrum również znajdowała się scena Wizji Ezechiela ${ }^{37}$. W górnej partii znalazło się przedstawienie emblematyczne identyczne jak w gdańskim epitafium Blemkego, wraz z inskrypcją „Mors spes alterae vitae”. Warto zauważyć, iż to samo motto pojawia się wraz z imago ukazującym scenę Wizji Ezechiela w jednym z emblematów Nicolausa Reusnera ${ }^{38}$.

W 1611 roku pomorski pastor luterański Joachim Saegerus pisał, iż obrazy, stanowiące część pomników nagrobnych, mają służyć pouczeniu wiernych ${ }^{39}$. O tym, jak mogła wyglądać realizacja tego zalecenia świadczy fragment jednego z publikowanych kazań Sebastiana Brotsorga zw. Artomedesem, kaznodziei dworu w Królewcu. Można wyobrazić sobie, jak wskazując jako exemplum jedno spośród dzieł sztuki sepulkralnej znajdujących się we wnętrzu kościoła, kaznodzieja zwraca się do wiernych słowami: „Es ist hie in unser Kirchen ein Epitaphium, wer ihm solches bestellet der muß freylich auch des thewren blutes Jesu Christi sich hertzlich getröstet haben. Denn da kniet er für dem gecreutzigen Jesu und lest das Blut welches aus Christi geöffneter seiten springet auff seine Brust fallen" ${ }^{\prime \prime}$. Epitafia Blemkego i Valentina von Bodeck zdają się być właśnie tego rodzaju przekazem kierowanym przez fundatorów

37 Nathan Chytreus, Variorum in Europa itinerum deliciae, seu, ex variis manuscriptis selectiora tantum inscriptionum maxime recuntium monumenta..., Christoph Rab, Herborn 1594, fol. 543. Chodzi tu zapewne o malowidło zniszczone w czasie pożaru w 1777 r., następnie określone przez Fuchsa jako „unkenntlich”, zob. Michael Gottlieb FucHs, Beschreibung der Stadt Elbing und ihres Gebietes in topographischer, geschichtlicher und statistischer Hinsicht, 2, Elbing 1821, s. $208-210$. Epitafium, przede wszystkim inskrypcje, przytoczone zostały ponadto w: Szymon StarowolskI, Monumenta Sarmatarum beatae aeternitati, Officina viduae et haeredum Francisci Caesarij, Cracoviae 1655, fol. 373; Gottfried ZAMEHL, Epitaphia aus der Pfaar oder St. Nicolai Kirche in Elbing [1575-1777], Rękopisy nieurzędowe, Archiwum Państwowe w Gdańsku (dalej cyt.: APG), sygn. 492/971, fol. 266; Georg Daniel SEYLER, Epitaphia aus allen Kirchen in und bei der Stadt Elbing [1558-1783], Rękopisy nieurzędowe, APG, sygn. 492/921, fol. 92; Johann Heinrich DEwITz, Epitaphia und Inscriptiones aller Kirchen der Städte Elbing und deren Territorii [1393-1746], Rękopisy nieurzędowe, APG, sygn. 492/317, fol. 9v-10.

38 Nikolaus Reusner, Emblemata Partim Ethica, Et Physica: Partim vero Historica \& Hieroglyphica (Frankfurt am Main 1581), Emblematisches Cabinet, ed. Michael ScHILlING, Hildesheim-Zürich-New York 1990, nr 35, s. 247-248.

39 Za: WisŁocki 2005, s. 46.

40 Cyt. za: Sebastian ArTomedes, Christliche Leichpredigten so bei unterschiedenen Leichenbegengnissem in der Fürstlichen Stadt Kneiphoff Königsberg in Preussen gehalten worden durch den Ehrwirdigen Achtbarn und Volgelarten Herrn M. Sebastinum Artomedum, Leipzig 1609, Die vierdte Leichpredigt, f. 80 (wyróżn. autora). Podobnego przykładu dostarcza m.in. Johann SpANGEnBERg, Funffzehen leichpredigt, so Man bej dem Begrebnis der verstorbenen, in Christlicher gemein thun mag, Wittemberg 1568, Die erste Leichpredigt, fol. 5v. Zob. też WiSŁOCKI 2005, s. 208. 
do współwyznawców, podobnym do przykładu użytego przez królewieckiego kaznodzieję.

Nie to było jednak celem Heinricha Strobanda, gdy wznosił w toruńskim kościele Mariackim pomnik swych przodków. Brak w nim bezpośrednich odniesień biblijnych, scen czy inskrypcji, które mogłyby posłużyć pouczaniu wiernych. Częściowo wynika to zapewne z jego przekonań religijnych, dydaktyczna funkcja obrazów stanowiła bowiem część doktryny luterańskiej. Jak pisał Marcin Luter $w$ fundamentalnym dla jego teologii obrazu dziele Wider die himmlischen Propheten z 1525 roku, przedstawienia - jak te wspomniane wyżej - były chrześcijańskim dziełem tworzonym „dla oglądu, dla świadectwa, dla pamięci, dla znaku"¹. Podążając za myślą św. Grzegorza Wielkiego wskazywał ponadto, iż obrazy takie poruszają przede wszystkim ludzi prostych, ułatwiając im zrozumienie Słowa Bożego ${ }^{42}$. Przekonanie to odrzucali jednak zwolennicy bardziej radykalnych ruchów reformatorskich, do których zazwyczaj zalicza się Heinricha Strobanda. Sympatiami tymi zapewne podyktowany był zresztą wybór pomnika inskrypcyjnego w miejsce epitafium obrazowego, do którego to typu zaliczają się inne monumentalne epitafia w tym samym kościele, upamiętniające członków rodzin Mochinger i Neisser. Z drugiej jednak strony Strobandowie nie wahali się umieścić pomnika w kościele Mariackim, skażonym kultem idoli, jak opisywał budowle sakralne wzniesione w średniowieczu na północy Europy w swym Ultima verba inny toruński kaznodzieja, Konrad Graser Starszy ${ }^{43}$. Kościół Mariacki pozostał zresztą główną świątynią protestancką Torunia, w końcu XVI wieku grupującą elity zorientowane na drugą reformację.

Wzniesione przez Heinricha Strobanda w głównej protestanckiej świątyni miasta dzieło stało się przede wszystkim pomnikiem rodu, niosącym pamięć o nim, a zarazem, poprzez inskrypcje, herby czy semantykę materiału - podkreślającym jego pozycję $w$ ówczesnym Toruniu. Immortalitas w zwieńczeniu jest tyleż nieśmiertelnością duszy, co nieśmiertelną chwałą Strobandów, która miała wynikać z ich cnoty, pozwalającej im na odczuwanie i manifestowanie uzasadnionej dumy. Zestawienie bogatego programu biograficznego z brakiem bezpośrednich odniesień biblijnych, zarówno w sferze obrazowej, jak i tekstowej, jest tu wręcz uderzające. Celem pomnika Strobandów nie było pouczenie ani wzmocnienie wiary, a upamiętnienie zmarłych członków rodziny, podkreślenie jej związków z pruską elitą oraz stworzenie wizji kontynuacji.

41 Sergiusz Michalski, Protestanci a sztuka. Spór o obrazy w Europie nowożytnej, Warszawa 1989, s. 53-54.

42 TAMŻE, s. 56-57.

43 O tym SKIBIŃSKI 2011. 


\section{Franciszek Skibiński \\ Faculty of Fine Arts, Nicolaus Copernicus University in Toruń}

\section{The monument of the Stroband family located in the Assumption of the Blessed Virgin Mary Church in Toruń and its content}

This article aims to analyze one of the most significant monuments of early modern art in Torun, the epitaph of Christian and Johann Stroband from 1590, which stands in the Assumption of the Blessed Virgin Mary Church, and to discuss its content and its context within the social framework of the city. The monument is presented here as a rich and significant source of knowledge on the political and intellectual culture of the city and its inhabitants. The first section of the article focuses on the issue of the authorship of the piece which it is usually attributed to Willem van den Blocke, a Netherlandish sculptor active in Gdańsk. The author of the article will attempt to support this attribution, by showing to the close similarities of the Stroband monument to other works connected to van den Blocke's workshop, particularly architecture and figurative sculpture. The links between the Stroband monument and the epitaph of Eduard Bleme in the St. Mary Church in Gdańsk will be of particular importance.

In the next part of the article, the content and message conveyed by the sculpture will be discussed. The author will also consider the role played by the monument in the social space of the city. In his discussion of the composition of the sculpture, the author indicates how its most important elements, for example the inscriptions and heraldry, served to emphasize the history of the family, the offices held by its members, its continuity and dignity, noble relations, and finally the relations of the family with other patrician houses of Prussia. In the context of the composition of the piece, the author refers to the eulogy to Johann Stroband which was written by Martin Trisner, a pastor and school professor in Torun, in which the role of sepulchral art is defined. In order to demonstrate the wider context, a number of emblematic prints, as well as other works of sepulchral art created in contemporary Royal Prussia are discussed. The author argues that the aim of the epitaph of the Stroband family was to commemorate the dead members of the family rather than to teach or strengthen viewers' faith, this was achieved through the emphasis on the family's connection to Prussian elites and the image of continuity. The sculpture erected by Heinrich Stroband, was a monument to his line; it preserved its memory and emphasized the social status of Heinrich Stroband and his family in Torun through the inscriptions, coats of arms and semantics of the material. 
Pomnik rodziny Strobandów w kościele pw. Wniebowzięcia NMP w Toruniu i jego treści

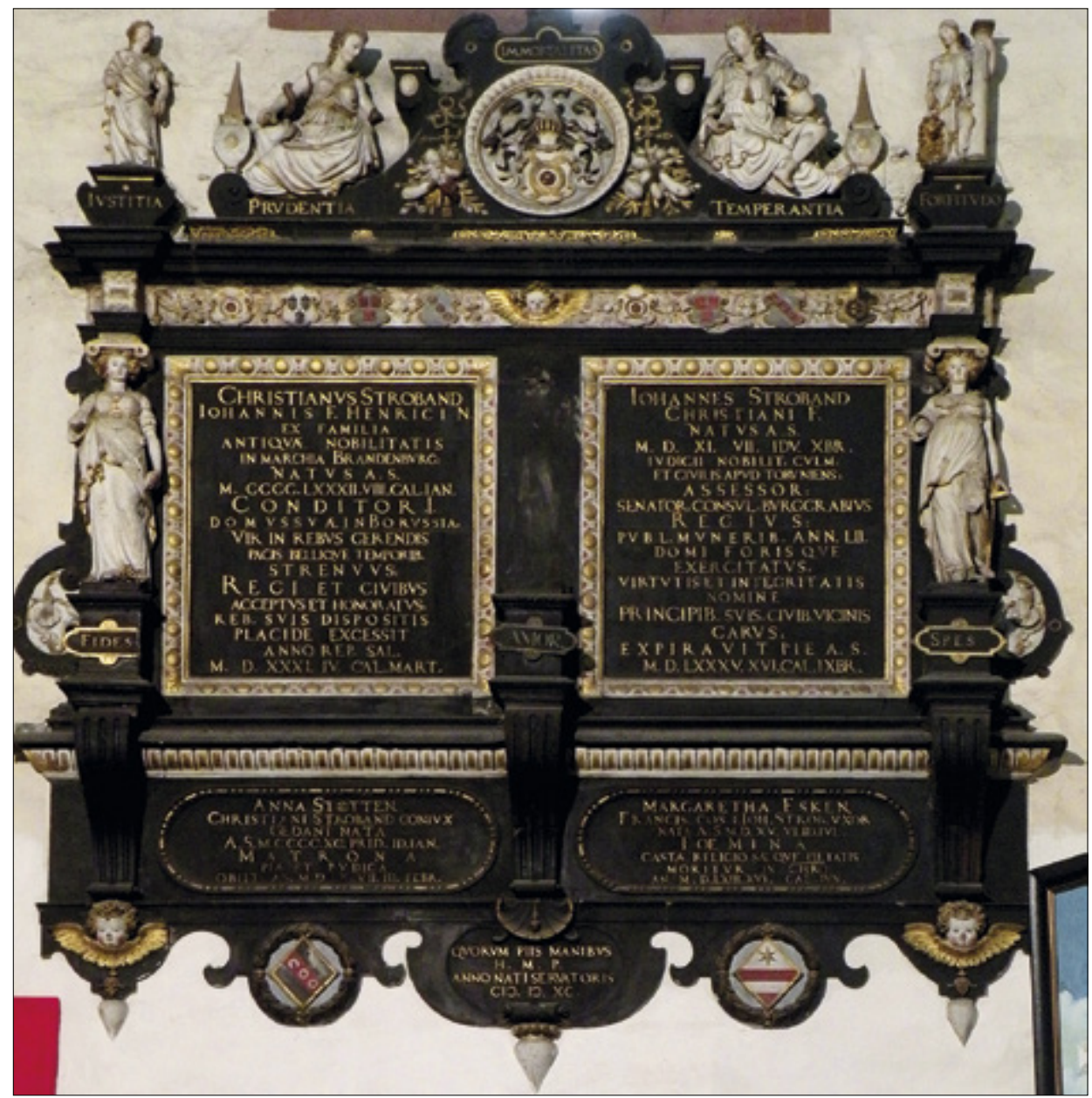

Il. 1. ToRuŃ, kościół pw. Wniebowzięcia NMP, pomnik Christiana i Johanna Strobandów. Fot. F. Skibiński 


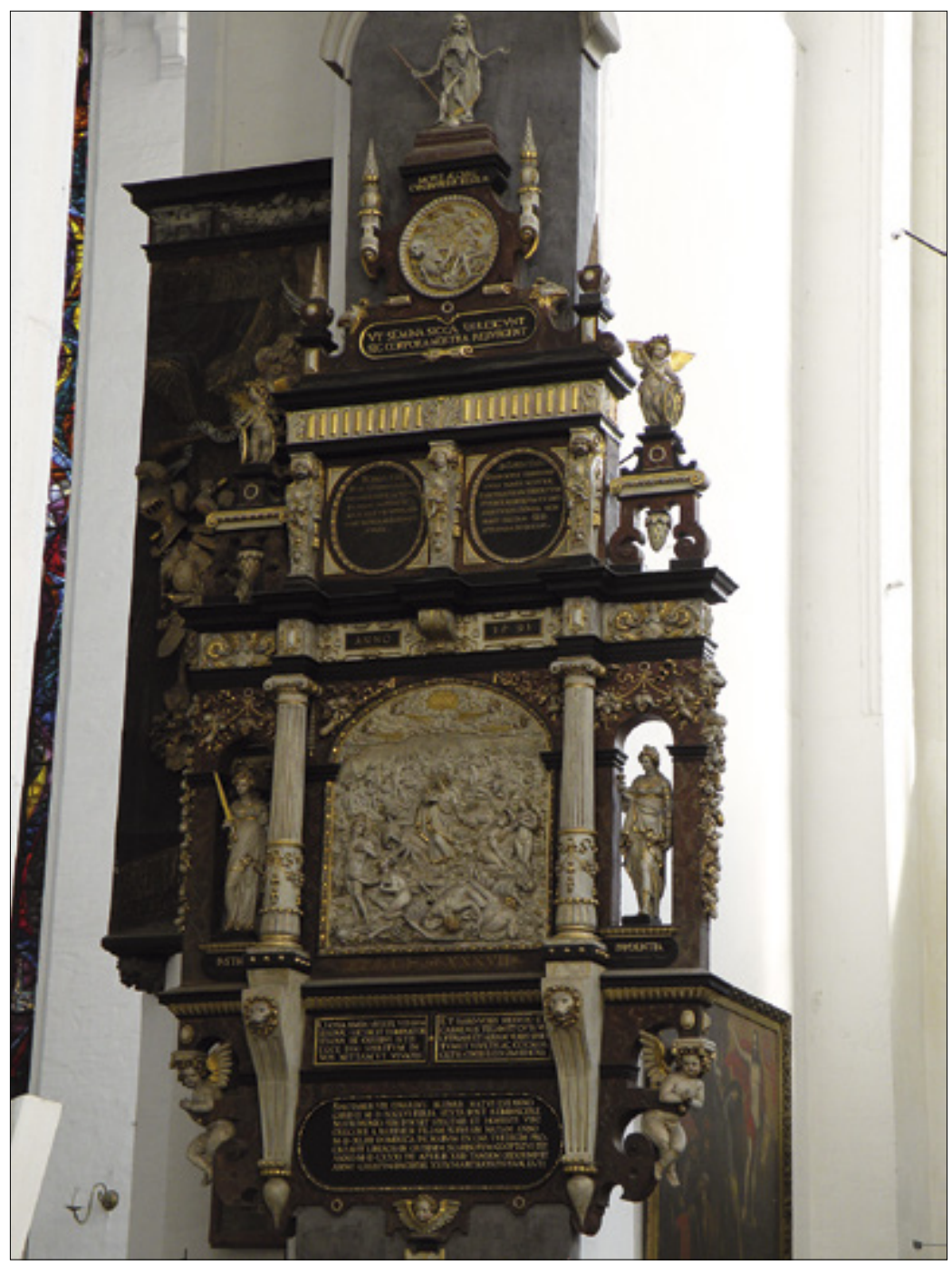

Il. 2. GDAŃsK, kościół pw. Wniebowzięcia NMP, epitafium Eduarda Blemke. Fot. F. Skibiński 
Pomnik rodziny Strobandów w kościele pw. Wniebowzięcia NMP w Toruniu i jego treści

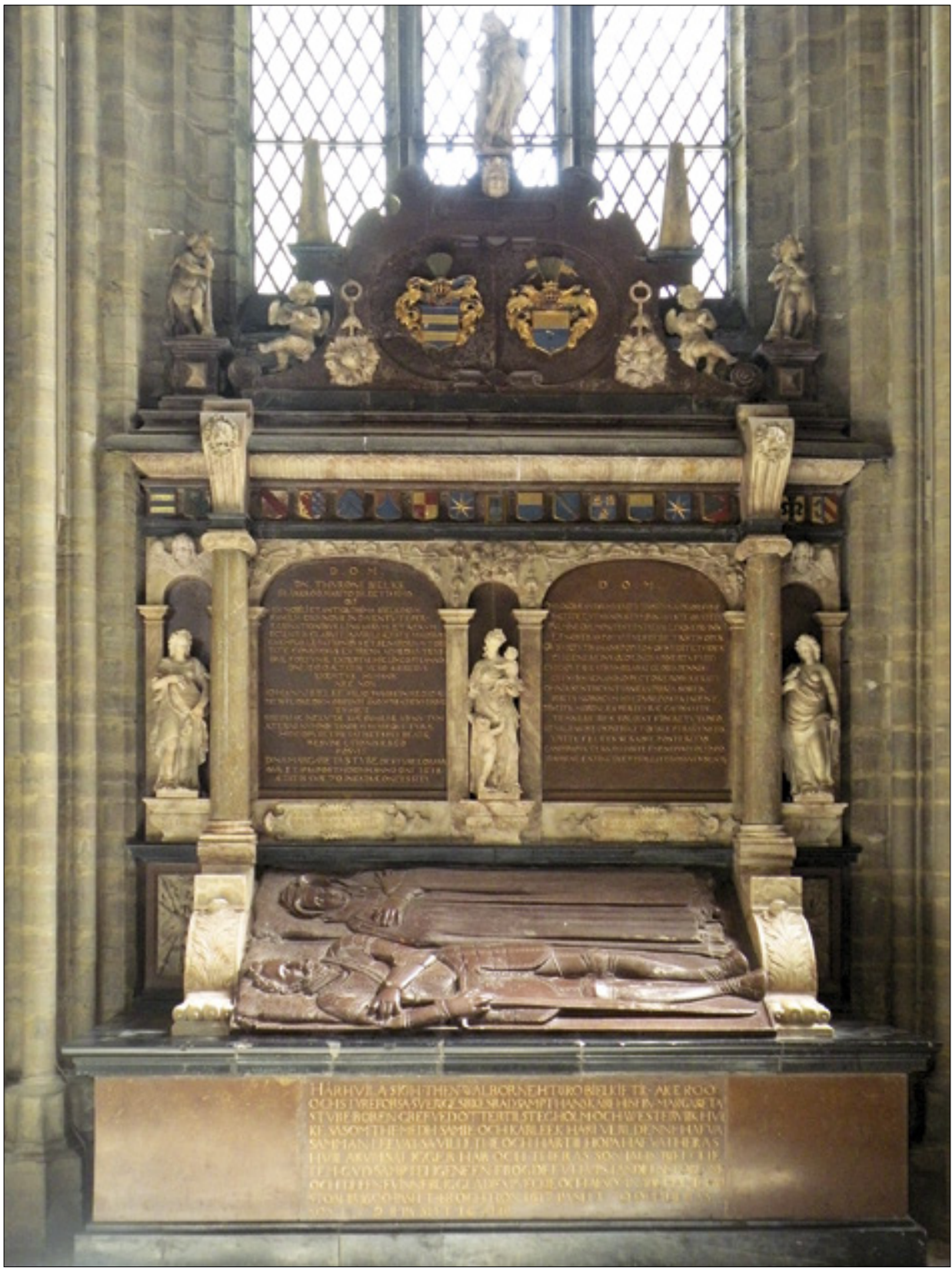

Il. 3. LINKöPING, katedra, pomnik nagrobny Ture Bielke i Margarethy Sture. Fot. F. Skibiński 


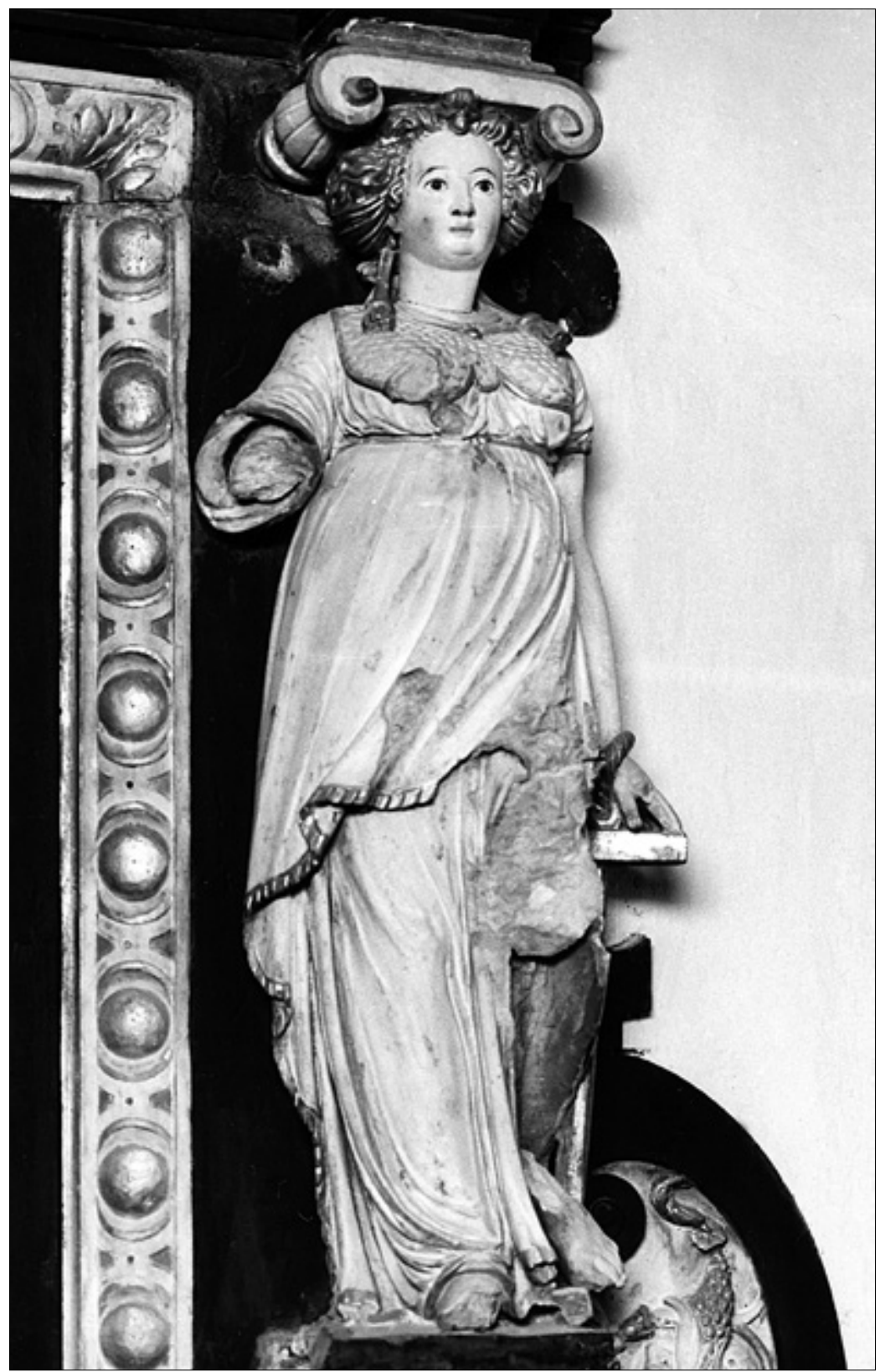

Il. 4. ToRuŃ, kościół pw. Wniebowzięcia NMP, pomnik Christiana i Johanna Strobandów, fragment. Fot. W. Górski 


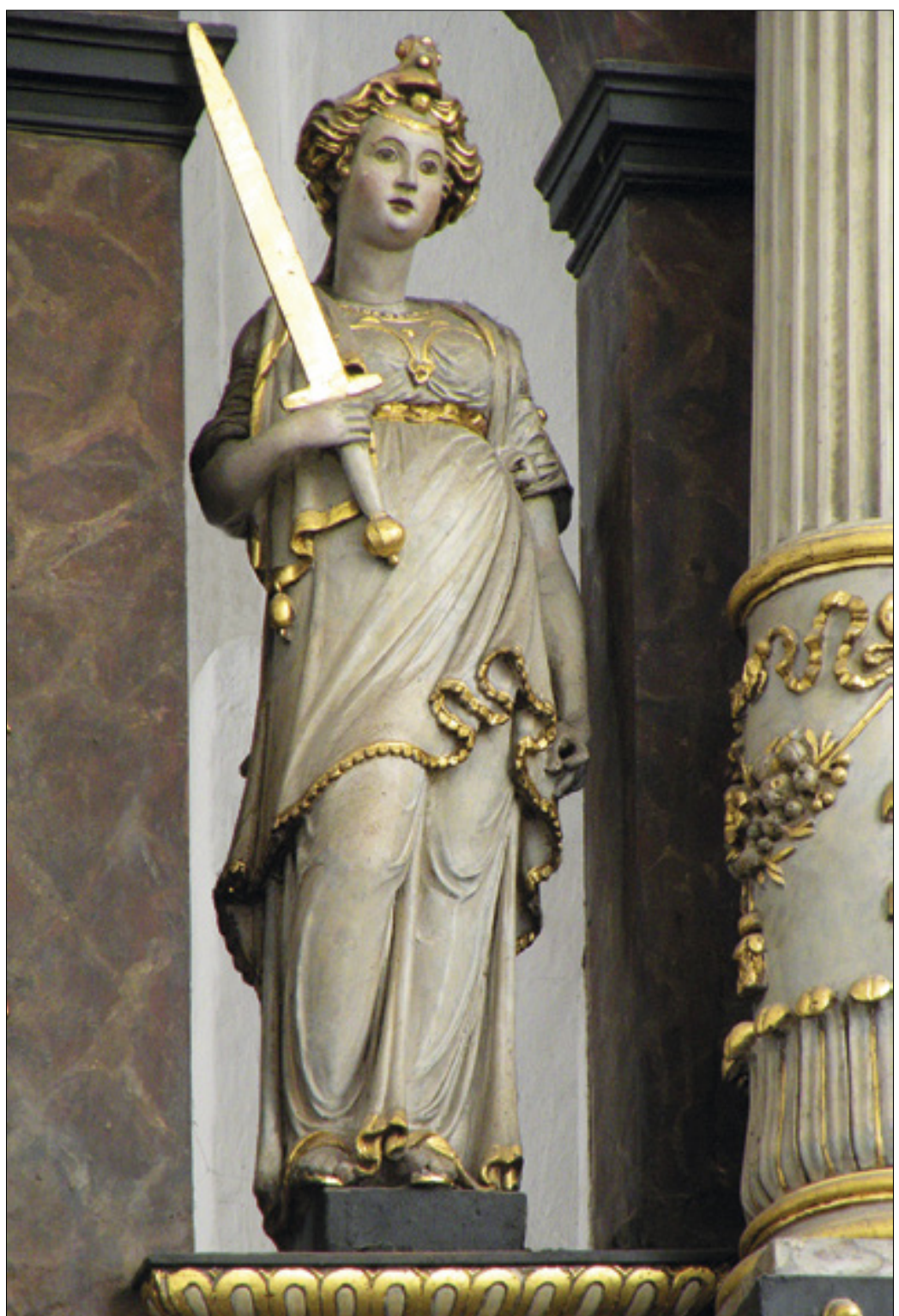

Il. 5. GDAŃSK, kościół pw. Wniebowzięcia NMP, epitafium Eduarda Blemke, fragment. Fot. F. Skibiński 


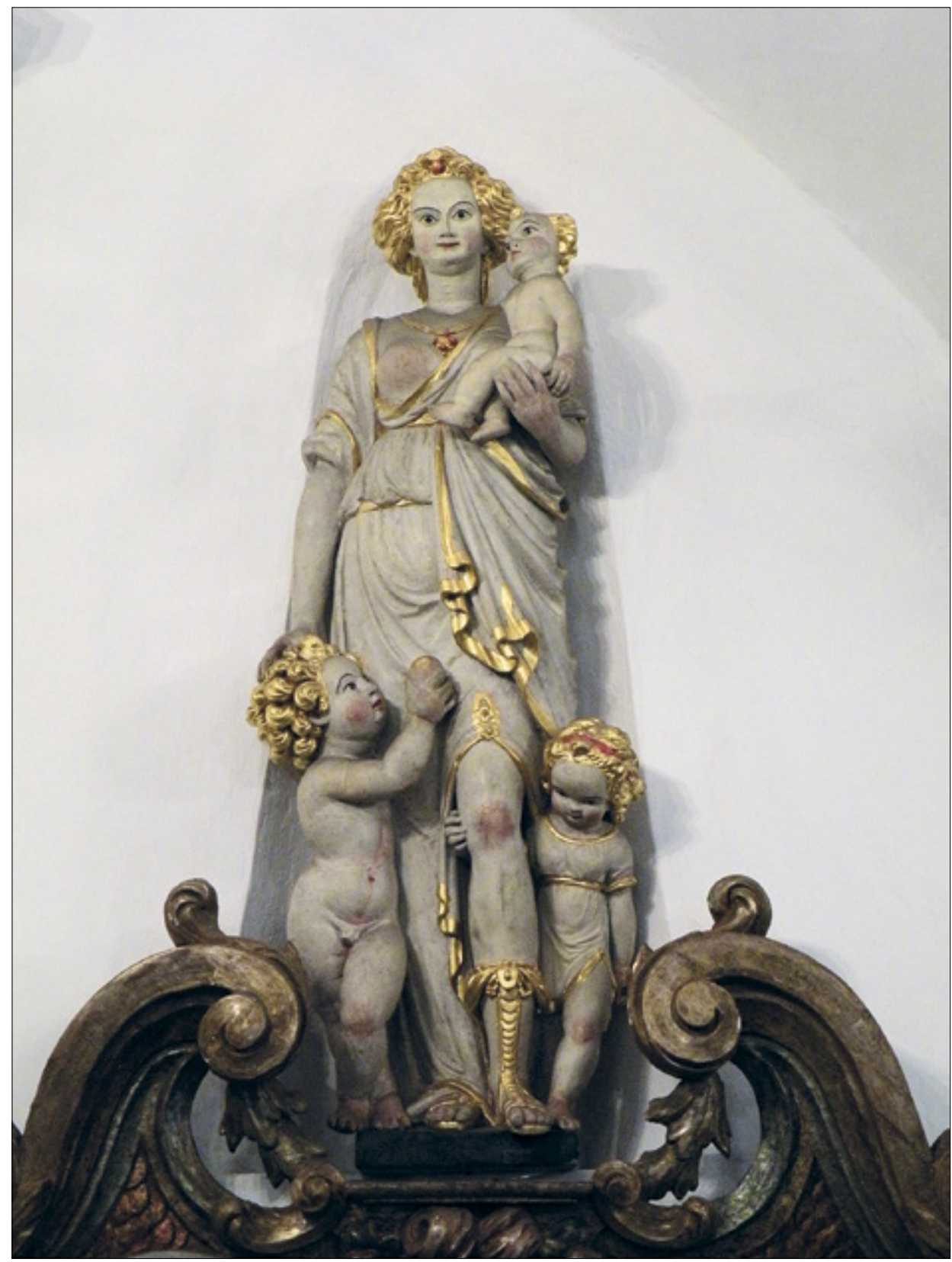

Il. 6. CheŁmno, ratusz, rzeźba Caritas, Fot. F. Skibiński (๑ Muzeum Ziemi Chełmińskiej) 


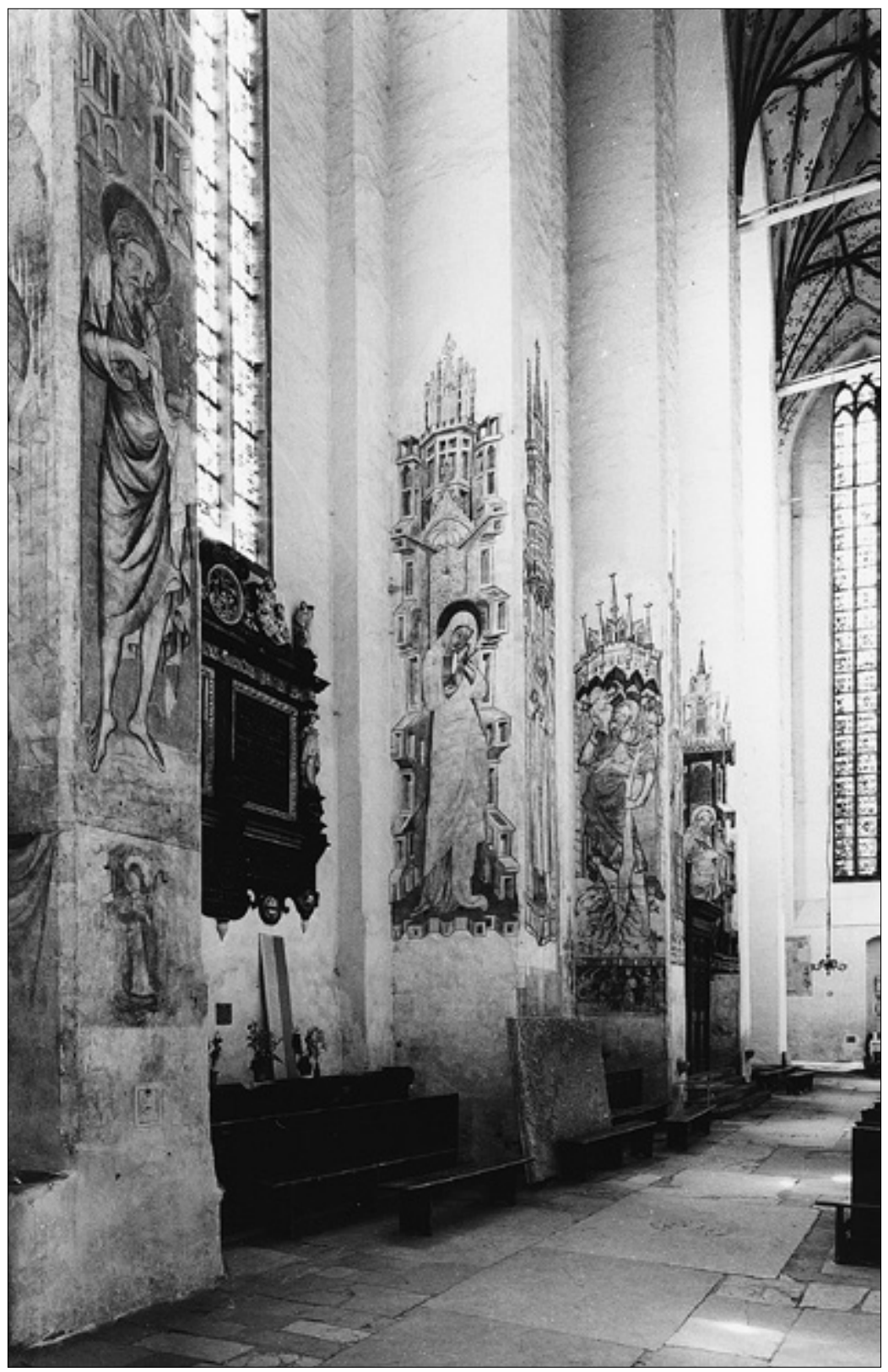

Il. 7. ToRuŃ, kościół pw. Wniebowzięcia NMP, pomnik Christiana i Johanna Strobandów w przestrzeni kościoła. Fot. W. Górski 


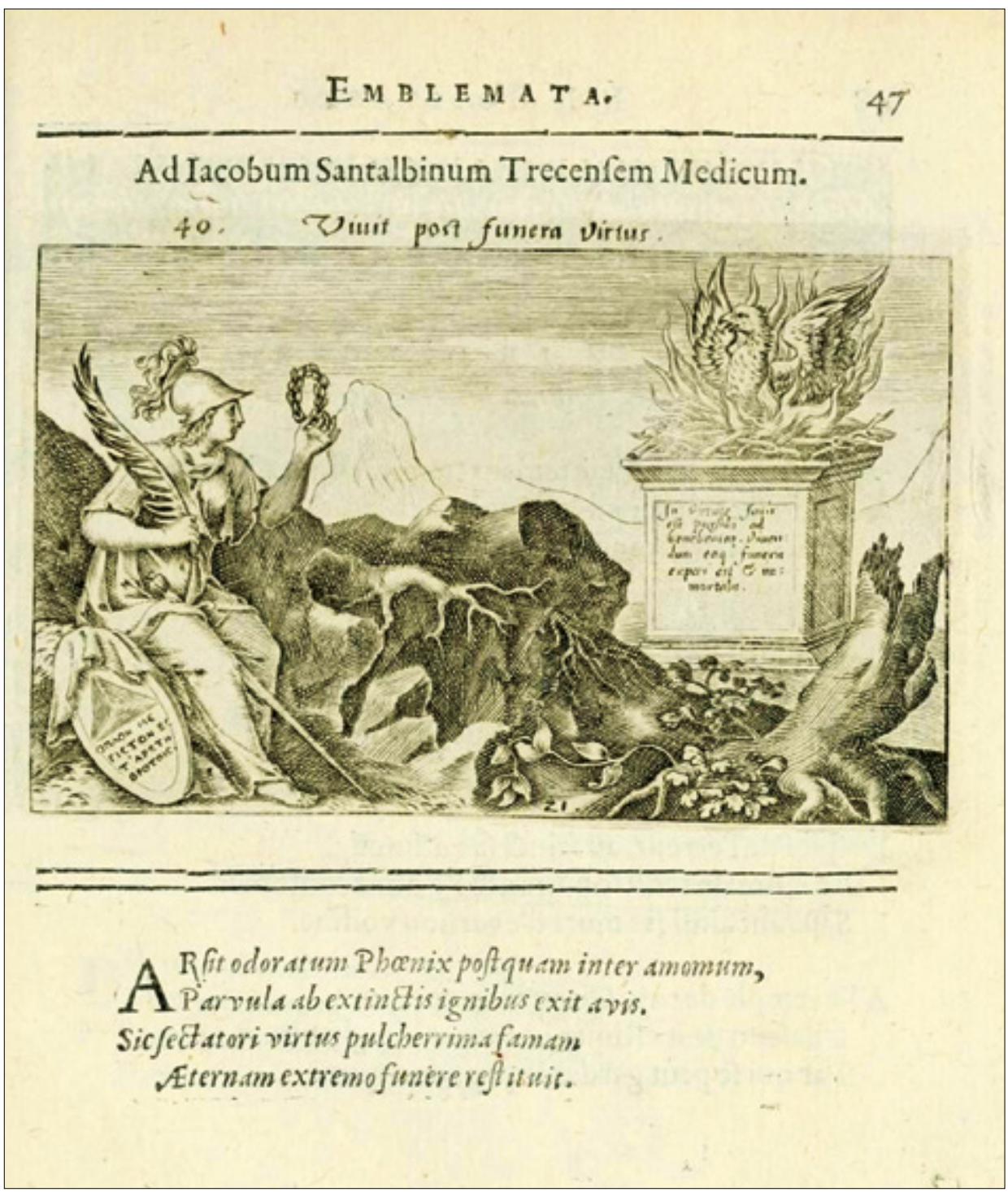

Il. 8. Jean-Jaques Boissard, Emblematum liber. Fot. wg https://archive.org/details/vesuntiniemblema00bois 


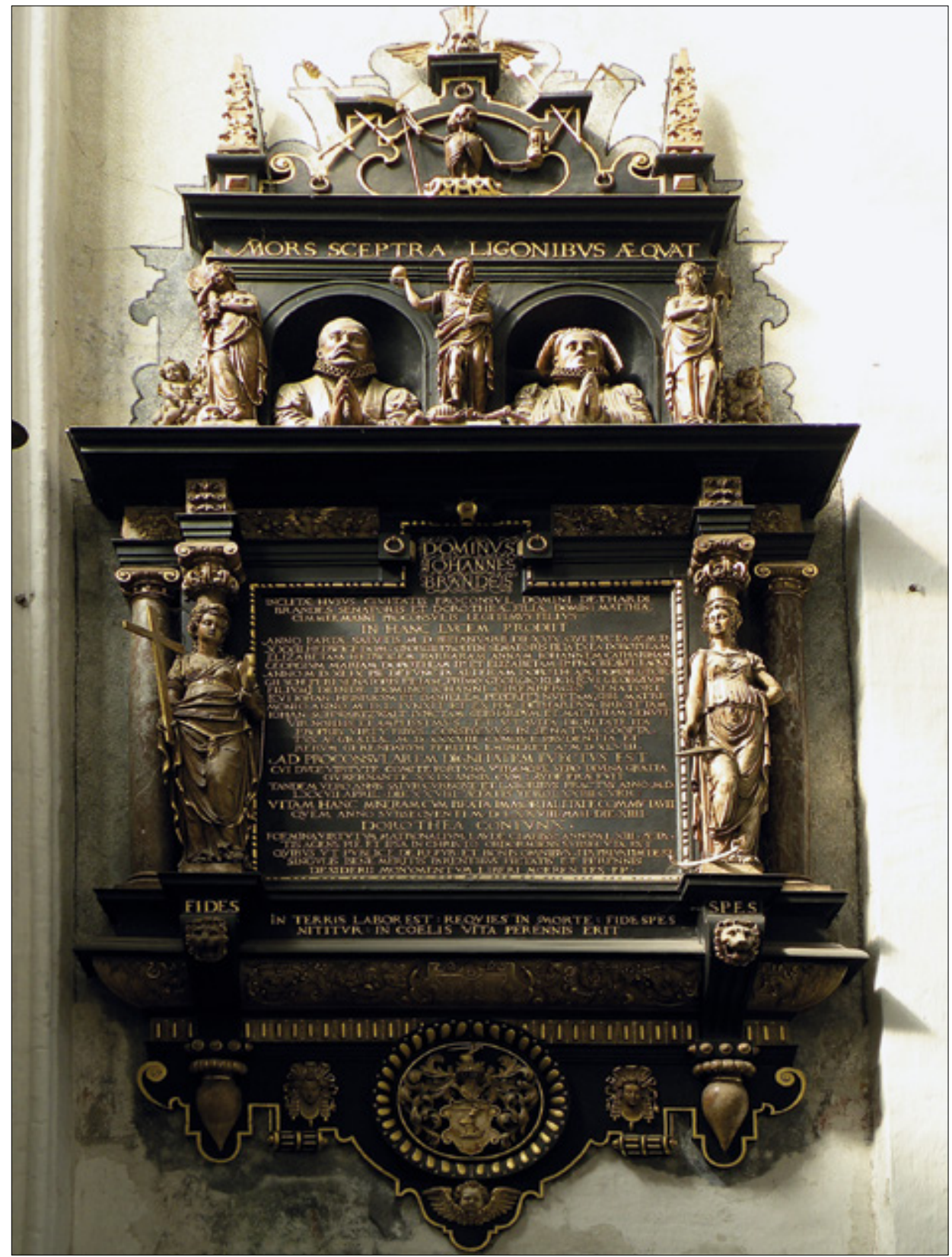

Il. 9. GDAŃsK, kościół pw. Wniebowzięcia NMP, pomnik Johanna Brandesa. Fot. F. Skibiński 


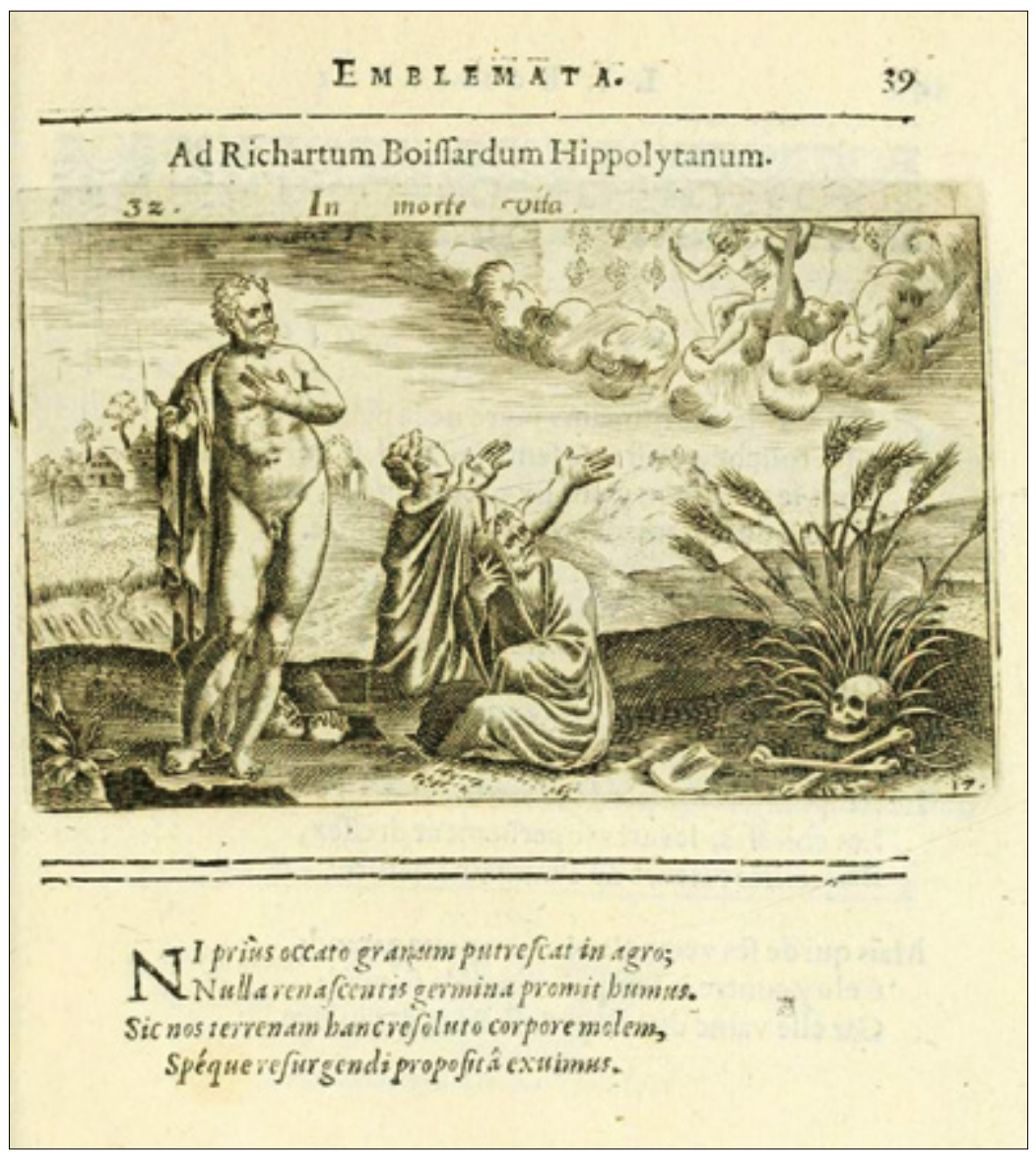

Il. 10. Jean-Jaques Boissard, Emblematum liber.

Fot. wg https://archive.org/details/vesuntiniemblema00bois 